\title{
Effect of heavy metal and some trace element levels on radiotherapy taken
}

\section{breast cancer patients}

\author{
Halit Demir ${ }^{1}$, Canan Demir ${ }^{2}$
}

\begin{abstract}
Objective: The aim of this article is to research the effects of radiotherapy on trace elements and heavy metals in patients with breast cancer. Breast cancer is a common disease worldwide. Breast cancer risk increases with age and occurs at much higher levels in postmenopausal women. During radiation therapy for the treatment of breast cancer, damage to tissue may result. Depending on the treatment technique applied, other areas apart from the treatment area may be affected. For example, the lungs may be negatively affected, resulting in decreased lung capacity. Consequently, free radicals may be formed as a result of oxidative stress incurred due to insufficient lung capacity
\end{abstract}

Plan and design: In this review article, approximately 110 articles were consulted.

Result: Radiotherapy may cause damage to or loss of tissue, and may have negative effects on trace element levels. Consequently, levels of heavy metals and trace elements may be altered during radiotherapy.

Conclusion; An increase in heavy metals leads to greater oxidative stress, which is associated with a higher risk of cancer. Normal levels of $\mathrm{Zn}$ may also decrease the risk of cancer.

Keywords: trace elements, heavy metals, radiation therapy.

\section{Introduction}

Breast cancer is a common disease worldwide. Breast cancer risk increases with age and occurs at much higher levels in postmenopausal women. Among women, breast cancer is the second most common type of cancer resulting in death, after lung cancer.

Radiation therapy can be used to treat all types of solid tumors including brain, breast, stomach, larynx, esophagus, and other head and neck cancers. Postsurgical radiotherapy can be used in the adjuvant treatment of breast cancer to prevent local recurrence. Radiotherapy is also used in order to prevent recurrence after a local recurrence, thus showing the importance of treatment modality.

Trace elements play a very important role in human health, even though they are found in very minute amounts. Levels of $\mathrm{Cu}$ and $\mathrm{Mg}$ before and after radiotherapy in breast cancer patients have been shown to be statistically significant when compared with a healthy control group [1]. Serum $\mathrm{Cu}$ levels were found to be lower in lung cancer patients than in healthy people [2]. Levels of $\mathrm{Ni}$ were found to be increased in 15 patients with breast cancer [3].
Manganese and zinc, which are necessary for the superoxide dismutase enzyme system to function, are known to inhibit radiation-induced toxicity. In a study on colorectal cancer patients, varying levels of $\mathrm{Fe}, \mathrm{Cu}$, $\mathrm{Mn}$ and $\mathrm{S}$ were found [1-4]. Levels of $\mathrm{Na}, \mathrm{Mg}, \mathrm{Ca}, \mathrm{Se}$, $\mathrm{Rb}$ and Mo were observed to decrease in the plasma of lung cancer patients undergoing radiotherapy. However, levels of $\mathrm{Al}, \mathrm{S}, \mathrm{V}, \mathrm{Fe}, \mathrm{Cu}, \mathrm{Al}, \mathrm{Co}, \mathrm{Co}, \mathrm{Mn}$, $\mathrm{Hg}$ and $\mathrm{Pb}$ increased [5]. While cadmium (Cd), cobalt $(\mathrm{Co})$, antimony $(\mathrm{Sb})$, barium $(\mathrm{Ba})$, mercury $(\mathrm{Hg})$ and lead $(\mathrm{Pb})$ levels were found to increase prior to radiotherapy, the levels remained constant following radiotherapy [5]. In a study conducted with patients with locally advanced lung cancer, head and neck cancers, and cervical cancer who underwent radiotherapy, Se levels were examined before and after radiotherapy. Se levels decreased in response to therapy, and the rise in SA levels was interpreted as an enhanced response [6].

Recently, $\mathrm{Zn}$ levels in breast cancer patients were found to be significantly higher than in the control group [7]. 
However, in another study, no significant difference between $\mathrm{Zn}$ levels inbreast cancer patients and the control group was observed [8]. In the literature, levels of $\mathrm{Fe}, \mathrm{Cu}$, and $\mathrm{Zn}$ are considered biomarkers of breast cancer [9]. $\mathrm{Cu}$ levels in breast cancer patients were also found to be higher than in the control groups in two separate studies $[8,9] . \mathrm{Cu}$ and $\mathrm{Zn}$ levels have been observed to increase in breast cancer patients compared to control groups [10]. The importance of $\mathrm{Zn}$ as a carcinogenic agent is still subject to controversy. $\mathrm{Zn}$ may influence some cancers in several ways [11]. Deficiencies of trace elements such as $\mathrm{Cu}$ and $\mathrm{Mg}$ have been implicated in various reproductive disorders including infertility, miscarriage, cancer of the reproductive organs, pregnancy-induced hypertension, placental abruption, premature rupture of membranes, still births and low birth weight [12]. Although little research on the interaction between $\mathrm{Co}$ and cancer has been published so far, a few studies which have been published are intriguing. Exposure to Co has been shown to convert human osteoblast-like cells into the tumorigenic phenotype and to activate the expression of genes related to cancer $[13,14]$. $\mathrm{Cd}$ is a very toxic heavy metal and, unlike organic compounds, it is not biodegradable and has a very long biological half-life [15]. In one study, increased Cd levels were found in the serum of lung cancer patients [16]. Usually, carcinogenic elements can act as epigenetic carcinogens and carcinogenic metals can be genotoxic [17]. In one study, significant differences in the levels of $\mathrm{Fe}, \mathrm{Cu}$ and $\mathrm{Zn}$, were detected in some types of cancer [18]. Fluctuations in the concentrations of elements such as $\mathrm{Zn}, \mathrm{Cu}, \mathrm{Mg}, \mathrm{Pb}, \mathrm{Mn}, \mathrm{Cd}$, $\mathrm{Co}$ and $\mathrm{Fe}$ were also detected at significant levels in the blood of ovarian cancer patients [19]. Significant changes in serum levels of trace elements have been observed in prostate cancer patients [20]. $\mathrm{Zn}$ concentrations in ovarian and cervical cancer patients have been reported at lower concentrations with respect to control groups $[21,22]$. Zn may be protective against lung cancer. In addition, it was found that low levels of zinc could induce the pathogenesis of lung cancer. Lower levels of zinc might have an important role in the pathogenesis of lung cancer [2]. In one study, levels of $\mathrm{Cd}$ and $\mathrm{Pb}$ were found to be increased in patients with malignant glioma cancers [23]. In another study, it was also shown that concentrations of $\mathrm{Cd}$ and $\mathrm{Pb}$ in the serum samples of patients with renal cancer were increased compared to the control group [24]. Serum trace elements were significantly lower in breast cancer patients compared to controls in one study [25]. In another study, $\mathrm{Zn}, \mathrm{Cu}, \mathrm{Se}$, and $\mathrm{Fe}$ concentrations were high in cancer patients. In addition, in the same study, it was shown that the changes in trace element levels in serum and tissue might be of benefit as biomarkers during the initial plastic process [26]. Serum zinc levels were unchanged in patients with early breast cancer and benign breast disease [27]. Low selenium levels were detected in patients with diseases such as various cancers, muscular dystrophy and heart disease [28]. According to some studies, various trace elements were thought to play a role in carcinogenesis of breast cancer [29, 30]. Fe levels in breast cancer patients have been reported at higher concentrations with respect to control groups $[7,8]$.

The implementation of proper radiotherapy in the treatment of breast cancer can significantly prolong survival time in patients [31]. In one study, high $\mathrm{Cu} /$ $\mathrm{Zn}$ ratios following radiotherapy was found to be potentially useful in assessing possible improvements in breast cancer patients [10]. Although there have been some studies on breast cancer carcinogenesis, the role of trace elements has not been fully clarified yet [32]. For women in the United States, breast cancer continues to be one of the most common cancers [33, 34]. In one study, cadmium was found to cause early puberty and possibly increase the risk of breast cancer [35]. In a recent study, cadmium was reported to cause DNA damage in breast cancer patients [36]. Lead levels in breast cancer patients' tissue were significantly higher in both malignant and benign tissue [37]. In a study of 20 breast cancer patients, high nickel levels were found [38]. In another study, chromium levels were found to be significantly higher in breast cancer patients than in the control group [39]. Breast cancer patients were found to have significantly higher iron levels in another study [40]

\section{Result}

During radiation therapy for the treatment of breast cancer, damage may occur to tissue, even to tissue which is not located in the treatment area, depending on the treatment techniques applied. Radiotherapy may also cause loss of tissue, and may have negative effects on trace element levels. Consequently, levels of heavy metals and trace elements may be altered during radiotherapy. An increase in heavy metals leads to greater oxidative stress, which is associated with a higher risk of cancer. Normal levels of Zn may also decrease the risk of cancer.

\section{Conclusion}

As a result; radiotherapy for breast cancer should be examined, when the treatment of oxidative damage of the lung volume is controlled.

Acknowledgments: This research received no specific grant from any funding agency, commercial or not-for-profit sectors.

Conflict of Interest: The authors declare no potential conflicts of interest with respect to the research, authorship, and/or publication of this article. 


\section{References}

1. Seven G., 2010. Meme, Baş boyun ve Mide kanserl hastalarda Radyoterapi öncesi ve sonrası iz elementler ve ağır metal düzeylerinin $(\mathrm{Zn}, \mathrm{Cu}, \mathrm{Pb}, \mathrm{Cd}, \mathrm{Mn}, \mathrm{Mg}$ ve $\mathrm{Co})$ ve bazı biyokimyasal (katalaz ve karbonik anhidraz) parametrelerin incelenmesi. 2010. Yüzüncü Y1 Üniversitesi, Fen Bilimleri Enstitüsü, Kimya Anabilim Dalı, Biyokimya Bilim Dalı (yüksek lisans tezi), Van.

2. Cobanoglu U, Demir H, Sayir F, Duran M, Meran D. Some mineral, trace element and heavy metal concentrations in Lung Cancer. A. Pacific Journal of Cancer Prevention. 2010. 11, 1383-1388.

3. Kollmeier H, Seeman JW, Rothe G, Muller KM, Wittig P Increased chromium and nickel content in lung tissue and bronchial carcinoma. 1987. Am. J. Ind. Med., 11: 659-669.

4. David M, Ondrej N, Vaclav S, Kamil V, and Jindrich M Serum levels of selenium, manganese, copper, and iron in colorectal cancer patients. Biological Trace Element Research. 2001. Volume 79, Number 2, Pages 107-114.

5. Cavusoglu K, Cakır AS, Kurtman C. Radyoterapi Gören Akciğer Kanseri Hastaların Plazma İz Element Düzeylerindeki Değişimin Belirlenmesi. F.U. Sag. Bil. Derg. 2008: 22 (4): $211-222$

6. Dubova S, Özsaran Z, Kamer S, Haydaroğlu A. Radikal radyoterapi uygulanan lokal ileri evre akciğer, baș-boyun ve serviks kanserlerinde serum selenyum düzeyi ve tedaviye yanıt ile ilişkisi. Türk Onkoloji Dergisi. 2006; 21(3): 107-114.

7. Feng JF, Lu L, Zeng P, Yang H, Luo J, Yang Y, Wang D. Serum total oxidant/antioxidant status and trace element levels in breast cancer patients. International journal of clinical oncology. 2012; 17(6):575-83.

8. Huang YL, Sheu JY, Lin TH. Association between oxidative stress and changes of trace elements in patients with breast cancer. Clinical Biochemistry. 1999; 32(2) 131 136.

9. Kuo HW, Chen SF, Wu CC, Chen DR, Lee JH. Serum and tissue trace elements in patients with breast cancer in Taiwan. Biol Trace Elem. Res. 2002; 89:1-11.

10. Toy A. Meme kanserli hastalarda tedavi oncesi ve sonrasi total antioksidan kapasite eser elementler ve lipid peroksidasyonu. 2012. Trakya Üniversitesi Sağlık Bilimleri Enstitusu Biyofizik Anabilim Dali (yuksek lisans tezi) Edirne.

11. Prasad AS, Beck FWJ, Endre L, Handschu W, Kukuruga M, Kumar G. Zinc deficiency affects cell cycle and deoxythymidine kinase (TK) gene expression in HUT-78 cells. J Lab Clin Med. 1996; 128(1): 51-60.

12. Pathak P, Kapil U. Role of trace elements zinc, copper and magnesium during pregnancy and its outcome. Indian $\mathrm{J}$ Pediatr. 2004; 71(11):1003-1005.

13. Miller AC, Mog S, McKinney L, Luo L, Allen J, Xu J, and Page N. Neoplastic transformation of human osteoblast cells to the tumorigenic phenotype by heavy metaltungsten alloy particles: induction of toxic effects. Carcinogenesis. 2001; 22(1):115-125.
14. Miller AC, Brooks K, Smith J, Page N. Effect of the militarily relevant heavy metals, depleted uranium and heavy metal tungsten-alloy on gene expression in human liver carcinoma cells (HepG2). Mol Cell Biochem. 2004; 255(1-2): 247-256

15. Ilıcin G. Serum copper and magnesium levels in leukemia and malignant Iymphoma. Lancet. 1971; 2(7732):10361037.

16. Cobanoglu U, Demir H, Sayir F, Duran M, Meran D. Some mineral, trace element and heavy metal concentrations in Lung Cancer, A. Pacific Journal of Cancer Prevention. 2010; 11,1383-1388.

17. De Palma G, Goldoni M, Catalani S, Carbognani P, Poli D, Mozzoni P, Acampa O, Internullo E, Rusca M, Apostoli P. Metallic elements in pulmonary biopsies from lung cancer and control subjects. Acta Biomed. 2008; 79 (Suppl 1): 43 51

18. Kaba M, Pirinçç NÜ, Yüksel MB, Geçit İ, Güneş M, Demir M, Akkoyun HT, Demir H. Serum Levels of Trace Elements in Patients with Testicular Cancers. Int Braz J Urol. 2015; 41: 1101-07.

19. Bilici M, Cim N, Demir H. Examination of preoperative and postoperative levels of rare earth elements $(\mathrm{Zn}, \mathrm{Cu}$, $\mathrm{Mg}, \mathrm{Pb}, \mathrm{Mn}, \mathrm{Cd}, \mathrm{Co}$ and $\mathrm{Fe}$ ) in the blood of ovarian cancer patients. Medical Science and Discovery. 2015, Vol. 2, No. 1, p:139-43.

20. Kaba M, Pirincci N, Yuksel MB, Gecit I, Gunes M, Ozveren H, Eren H, Demir H. Serum levels of trace elements in patients with prostate cancer. A. Pac J Cancer Prev. 2014;15(6): 2625-9.

21. Cunzhi H, Jiexian J, Xianwen Z, Jingang G, Shumin Z, Lili D. Serum and tissue levels of six trace elements and copper/ zinc ratio in patients with cervical cancer and uterine myoma. Biol Trace Elem Res. 2003; 94, 113-22.

22. Yaman M, Kaya G, Simsek M. Comparision of trace elements concentrations in cancerous and noncancerous human endometrial and ovary tissues. Int $\mathrm{J}$ Gynecol Cancer. 2007; 17, 220-8.

23. Arslan M, Demir H, Arslan H, Gokalp AS, Demir C. Trace elements, heavy metals and other biochemical parameters in malignant glioma patients. Asian Pac J Cancer Prev. $2011 ; 12,447-51$

24. Pirincci N, Gecit I, Gunes M, Kaba M, Tanik S, Yuksel MB, Arslan H, Demir H. Levels of serum trace elements in renal cell carcinoma cases. A. Pac J Cancer Prev. 2013; 14(1):499-502.

25. Arooj B, Ahmed S, Saleem M, Khurshid R, Zia M. Serum trace elements in diagnosis of breast malignancy. J Ayub Med Coll Abbottabad. 2012; 24(2):62-4.

26. Kuo HW, Chen SF, Wu CC, Chen DR, Lee JH. Serum and tissue trace elements in patients with breast cancer in Taiwan. Biol Trace Elem Res. 2002; 89(1):1-11.

27. Gupta SK, Shukla VK, Vaidya MP, Roy SK, Gupta S. Serum trace elements and $\mathrm{Cu} / \mathrm{Zn}$ ratio in breast cancer patients. J Surg Oncol. 1991; 46(3):178-81. 
28. Thomsen C D, and Robinson M F. Selenium in human health and disease with emphasis on those aspects peculiar to New Zealand. Am. J. Clin. Nutr. 1980; 33: 303-323.

29. Moore AB, Shannon J, Chen C, Ohanna WL, Roberta MR, Sharon KL, Minggang L, Helge S, and David BT.Dietary and stored iron as predictors of breast cancer risk: a nested case-control study in Shanghai. Int J Cancer. 2009; 125:1110-1117. 59

30. Andreini C, Bertini I, Cavallaro G, Gemma LH, Janet MT. Metal ions in biological catalysis: from enzyme databases to general principles. J Biol Inorg Chem. 2008; 13:12051218 .

31. Lemieux J, Goodwin PJ, Bordeleau LJ, Lauzier S, Théberge V. Quality-of-Life Measurement in Randomized Clinical Trials in Breast Cancer: An Updated Systemic Review (20012009). J Natl Cancer Inst. 2011; 103(3):178231.

32. Sharma K, Mittal DK, Kesarwani RC, Chowdhery L. Diagnostic and prognostic significance of serum and tissue trace elements in breast malignancy. Indian J Med Sci. 1994; 48:227- 232 .

33. Verkooijen HM, Fioretta G, Vlastos G, Morabia A, Schubert H, Sappino AP. Important increase of invasive lobular breast cancer incidence in Geneva, Switzerland. Int J Cancer. 2003; 104(6): 778-81. http://dx.doi.org/10.17546/msd.55299

34. American Cancer Society, Cancer Facts \& Figures, Breast Carcinoma In Situ, 2015, page; 26-28.

35. Johnson MD, Kenney N, Stoica A, Hilakivi-Clarke L, Singh B, Chepko G, et al. Cadmium mimics the in vivo effects of estrogen in the uterus and mammary gland. Nat Med. 2003. 9:1081-1084.

36. Roy SS, Mukherjee S, Mukhopadhyay S, Das SK. Differential effect of cadmium on cholinephosphotransferase activity in normal and cancerous human mammary epithelial cell lines. Mol Cancer Ther. 2004.3(2):199-204.

37. Siddiqui MK, Jyoti, Singh S, Mehrotra PK, Singh K, Sarangi R. Comparison of some trace elements concentration in blood, tumor free breast and tumor tissues of women with benign and malignant breast lesions, an Indian study. Environ Int. 2006. 32(5):630-7.

Ionescu JG, Novotny J, Stejskal VD, Latsch A, BlaurockBusch E, Eisenmann-Klein M. Increased levels of transition metals in breast cancer tissue. Neuro Endocrinol Lett. 2006. 27(Suppl 1)

Kilic E, Saraymen R, Demiroglu A, Ok E. Chromium and manganese levels in the scalp hair of normal and patients with breast cancer. Biol Trace Elem Res. 2004. 102(13): 19-25.

40. Geraki K, Farquharson MJ, Bradley DA. Concentrations of $\mathrm{Fe}, \mathrm{Cu}$ and $\mathrm{Zn}$ in breast tissue, a synchrotron XRF study. Phys Med Biol. 2002. 47:2327-2339.

Copyright (C) 2014 The Author(s); This is an open-access article distributed under the terms of the Creative Commons Attribution License (http://creativecommons.org/licenses/by/4.0), which permits unrestricted use, distribution, and reproduction in any medium, provided the original work is properly cited. All Rights reserved by international journal of Medical Science and Discovery.

Medical Science and Discovery, 2016; 3(3): 116-9 